JKKP: Jurnal Kesejahteraan Keluarga dan Pendidikan

http://doi.org/10.21009/JKKP

DOI: doi.org/10.21009/JKKP.031.02

E-ISSN: 2597-4521

\title{
PENGARUH PENDIDIKAN KARAKTER ANTI KORUPSI DALAM KELUARGA TERHADAP KARAKTER ANTI KORUPSI PADA REMAJ A
}

\author{
Mega Novi Utami ${ }^{1, a)}$, Uswatun Hasanah ${ }^{1, b)}$, Tarma ${ }^{1, c)}$ \\ a)meganoviutami@gmail.com , b)us nina@yahoo.com , c)Tarmasae@gmail.com \\ 1Program Studi Pendidikan Kesejahteraan Keluarga \\ Fakultas Teknik, Universitas Negeri J akarta \\ J In. Rawamangun Muka, J akarta Timur. 13220
}

\begin{abstract}
Abstrak
Keluarga merupakan lingkungan yang paling utama untuk menentukan masa depan anak, demikian pula karakter anak yang baik dimulai dari keluarga. Keluarga yang bersikap permisif terhadap perilaku koruptif akan membuat anak memandang perilaku koruptif adalah sesuatu yang lumrah. Tujuan penelitian ini adalah untuk mengetahui dan menganalisis pengaruh pendidikan karakter anti korupsi dalam keluarga terhadap karakter anti korupsi pada remaja di SMA Negeri 53 Jakarta. Penelitian ini adalah penelitian kuantitatif dengan metode survey dan pendekatan korelasi bivariat. Populasi penelitian ini adalah seluruh siswa kelas X dan XI SMA Negeri 53 Jakarta dengan jumlah sampel penelitian sebanyak 224 responden. Data pengujian hipotesis menggunakan analisis parametrik yaitu uji P ears on P roduct Moment. Hasil perhitungan koefisien korelasi Pearson Product Moment menghasilkan rhitung sebesar 0,354 dan uji signifikansi korelasi menghasilkan thitung sebesar 5,642 lebih besar dari ttabel sebesar 1,971 $(\alpha=0,05 ; d k=222)$. Hal ini menjelaskan bahwa terdapat pengaruh yang positif dan signifikan antara pendidikan pendidikan karakter anti korupsi dalam keluarga terhadap karakter anti korupsi pada remaja. Hasil uji koefisien determinasi sebesar $12,5 \%$ yang menjelaskan besarnya pendidikan karakter anti korupsi dalam keluarga mempengaruhi karakter anti korupsi pada remaja dan sisanya $87,5 \%$ dipengaruhi oleh faktor lain yang tidak diteliti.
\end{abstract}

Kata Kunci: Pendidikan karakter, anti korupsi, remaja

\section{The Effect of Anti-Corruption Character Education in Family Against Anti- Corruption Character in Adolescent}

\begin{abstract}
Family is the most important environment to determine the child's future, as well as a good children's character starts from the family. Families who has more permissive attitude towards corrupt behavior will make the child looked at corrupt behavior is commonplace. The purpose of this study was to determine and analyze the effect of anti-corruption education character in the family against adolescent character of anticorruption in SMAN $53 \mathrm{~J}$ akarta. This research is quantitative research with survey method and approach bivariate correlations. The study population was all students of class X and XI SMA Negeri $53 \mathrm{~J}$ akarta as many as 224 respondents. Data of hypotesis testing using parametric analysis Pearson Product Moment test. The result of the calculation correlation coefficient of Pearson Product Moment is rcount $=0.354$ and the significance test of correlation is tcount $=5.642$ greater than ttable $=1.971(\alpha=0.05 ; \mathrm{df}=$ 222). This explained that there is a positive and significant influence between education character of anti-corruption in the family against anti-corruption character in
\end{abstract}


adolescents. The result of determination coefficient of $12.5 \%$, which explains the magnitude of anti-corruption education in the family character affect the character of the anti-corruption in adolescents and the remaining $87.5 \%$ influenced by other factors not examined.

Keywords: character education, anti-corruption, adolescents

\section{PENDAHULUAN}

Korupsi telah dinyatakan sebagai kejahatan luar biasa. Hal ini karena dampak perilaku korup yang telah menjangkau seluruh aspek kehidupan bangsa, sehingga semua sektor kenegaraan mengalami kerusakan. Dampak korupsi dapat dibuktikan dengan angka pengangguran yang tinggi, tingkat pendidikan yang rendah, angka putus sekolah yang tinggi, kualitas kesehatan masyarakat masih buruk, pendapatan per kapita masih rendah, kriminalitas yang tinggi, daya beli masyarakat di daerah yang rendah dan kualitas sektor industri yang masih buruk (KPK, 2014: 36-37). Jika kondisi ini dibiarkan, negara dapat menuju arah kehancuran.

Tingkat korupsi di Indonesia tercatat cukup tinggi. Tahun 2014, Corruption Perception Index Indonesia berada di urutan ke-107 dari 174 negara. Indonesia tertinggal jauh dari negara tetangga seperti Singapura dengan urutan ke-7, Malaysia di urutan ke-50 dan Thailand di urutan ke-85 (Transparency International, 2014:3). Tahun 2013, nilai Indeks Persepsi Korupsi (IPK) yang dikeluarga oleh lembaga yang sama, Indonesia memperoleh skor sebesar 3,2 dari total 10 poin yang berarti Indonesia masih merupakan negara dengan tingkat korupsi yang tinggi (Wijaya,2014:5). Fenomena di atas menunjukkan bahwa negeri ini berada dalam krisis degradasi moral yang memunculkan karakter masyarakat yang mengukur segala sesuatu dari aspek materil. Tindakan melakukan korupsi selalu terkait dengan karakter seseorang (Suwarsono, 2015: 162).

Tindak pidana korupsi yang dilakukan oleh pejabat negara telah ditunjukkan oleh remaja dengan perilaku koruptif. Hal ini karena perilaku koruptif merupakan benih terjadinya tindak pidana korupsi. Penyebab munculnya perilaku koruptif pada remaja adalah tiadanya karakter jujur dalam diri remaja. Ketidakjujuran siswa salah satunya adanya mengenai kecurangan dalam Ujian Nasional (UN) yang masih marak terjadi. Pada UN 2015, Federasi Serikat Guru Indonesia (FSGI) menjelaskan bahwa masih terjadi praktik-praktik kecurangan ujian seperti jual beli jawaban UN baik secara individu maupun kolektif, modus mencontek dengan menggunakan handphone dan kertas sobekan serta kecurangan dengan melibatkan tim sukses UN di sekolah maupun dinas pendidikan. Selain itu, kantin kejujuran yang didirikan dengan harapan menumbuhkan karakter jujur siswa nyatanya hanya beberapa yang dikategorikan berhasil dan sisanya mengalami kebangkrutan (Rachim dalam ICW, 2010). Hal ini karena ketidakjujuran para siswa yang mengambil jajanan tanpa membayar.

Perilaku koruptif yang ditunjukkan remaja dikarenakan minimnya pendidikan karakter anti korupsi pada remaja. Saat ini pendidikan karakter anti korupsi masih dibebankan pada ranah formal yaitu institusi sekolah melalui pelajaran Pendidikan Kewarganegaraan (PKn), Pendidikan Agama dan Bimbingan Konseling. Namun, ternyata semua itu belum cukup untuk menangani masalah perilaku koruptif remaja. Untuk dapat membangun perilaku moral anti korupsi melalui karakter anti korupsi pada remaja diperlukan pembinaan intensif yang dimulai dari keluarga.

Keluarga merupakan lingkungan yang paling utama untuk menentukan masa depan anak, demikian pula karakter anak yang baik dimulai dari keluarga (Megawangi, 2009: 44). Keluarga yang bersikap permisif terhadap perilaku koruptif akan membuat anak memandang perilaku koruptif adalah sesuatu yang lumrah. Levine dalam Sjarkawi (2008: 20) menegaskan bahwa karakter yang tercipta dalam diri anak adalah akibat yang ditimbulkan karena meniru cara berfikir dan perbuatan yang sengaja maupun tidak sengaja dipraktikkan oleh orang tua. Kasus korupsi pengadaan Al Qur'an yang dilakukan oleh Menteri Agama Suryadharma Ali dan anaknya 
memberikan pelajaran bahwa lingkungan keluarga utamanya orangtua berperan besar dalam pembentukan karakter anti korupsi. Perilaku korup dapat terjadi karena dorongan keluarga (Kementrian Pendidikan dan kebudayaan, 2011: 48).

Permasalahan baru yang kemudian muncul adalah, dekade ini, banyak keluarga mengalami perubahan fungsi dan peran para anggotanya. Tekanan ekonomi sebagai dampak globalisasi membuat para ibu harus ikut bekerja mencari nafkah. Ibu bekerja tidak hanya dihadapi oleh penduduk miskin, namun juga keluarga kelas menengah ke atas. Tuntutan kebutuhan yang terus meningkat membuat kedua orang tua merasa wajib untuk mencari nafkah untuk memenuhi kebutuhan keluarga. Ketidakhadiran orangtua dalam keseharian anak menjadi faktor tidak berjalannya fungsi pendidikan dalam keluarga. Akibatnya, anak kehilangan sosok panutan.

Kurangnya pengetahuan dan kesadaran mengenai pendidi kan anti korupsi dalam keluarga membuat para orang tua tidak dapat memberikan contoh perilaku anti korupsi secara benar. Banyak dijumpai kasus orang tua yang telah menyiapkan sejumlah uang untuk anaknya masuk ke sekolah yang diinginkan, orang tua yang menyarankan anaknya mengurus SIM dengan menyuap, memberikan uang kepada guru sebagai hadiah kenaikan kelas anaknya, menitipkan anaknya bekerja dengan bantuan koneksi, tidak terbuka mengenai asal-usul penghasilan keluarga, berlibur dengan keluarga menggunakan mobil dinas, melanggar lalu lintas saat berkendara dengan keluarga dan perilaku koruptif lainnya. Semua itu adalah kasus pendidikan anti korupsi yang salah dalam keluarga, namun masih marak dijumpai.

Upaya penanggulangan korupsi bukanlah semata-mata tugas Komisi Pemberantasan Korupsi (KPK), melainkan tugas semua pihak untuk melakukan upaya preventif. Keluarga sebagai institusi utama penanaman karakter memegang peranan penting dalam pencegahan tindak korupsi/perilaku koruptif melalui pendidikan karakter anti korupsi. Pengkajian akan pentingnya peran keluarga dalam penanaman anti korupsi perlu segera disegerakan untuk mencegah bangsa ini hancur karena korupsi. Institusi keluarga yang terus mengalami kekacauan peran dan fungsi akan berdampak pada seluruh tatanan masyarakat dan kenegaraan. Berdasarkan latar belakang tersebut, maka dapat dirumuskan permasalahan penelitian sebagai berikut: "Apakah terdapat pengaruh antara pendidikan karakter anti korupsi dalam keluarga terhadap karakter anti korupsi terdiri dari jujur, peduli, mandiri, disiplin, tanggung jawab,

\section{METODOLOGI PENELITIAN}

Penelitian ini adalah penelitian kuantitatif dengan metode survey dan pendekatan korelasi bivariat. Populasi penelitian ini adalah seluruh siswa kelas X dan XI SMA Negeri 53 Jakarta dengan jumlah sampel penelitian sebanyak 224 responden. Data pengujian hipotesis menggunakan analisis parametrik yaitu uji Pearson Product Moment.

\section{HASIL DAN PEMBAHASAN}

Hasil penelitian menggambarkan bahwa nilai koefisien korelasi rhitung $=0,354$ dan thitung $=$ 5,642 lebih besar dari tabel $=1,971$ yang berarti terdapat pengaruh yang positif dan signifikan antara Pendidikan karakter anti korupsi dalam keluarga terhadap karakter anti korupsi pada remaja di SMA Negeri 53 Jakarta. Pengaruh yang signifikan ini seperti apa yang diungkapkan bahwa penanaman nilai-nilai atau internalisasi karakter antikorupsi dimulai dari lingkungan keluarga. Selain itu menurut Baseline Study Pembangunan Budaya Anti Korupsi Berbasis Keluarga yang dilakukan KPK 2012-2013 di Kota Yogjakarta dan Solo, menunjukkan bahwa ibu memiliki peran sangat penting, terutama dalam penanaman/ pendidikan nilai dan pembentukan karakter salah satunya adalah nilai kejujuran yang bisa menghancurkan korupsi (KPK, t.th: v). Agar pendidikan karakter anti korupsi dalam keluarga dapat berjalan dengan baik, maka KPK (t.th: 9) menjelaskan bahwa keluarga 
perlu menyadari perannya dalam pemberantasan korupsi, mengetahui manfaat yang diperoleh jika pencegahan korupsi berbasis keluarga ini berhasil, mengetahui apa yang harus dilakukan untuk mewujudkan impian tersebut dan mampu melakukan internalisasi nilai-nilai sehingga anak berperilaku jujur.

Korelasi penelitian ini masuk dalam kategori rendah dan berkorelasi positif. Besarnya sumbangan pendidikan karakter anti korupsi dalam keluarga terhadap karakter anti korupsi pada remaja adalah $12,5 \%$, sehingga semakin baik pendidikan karakter anti korupsi dalam keluarga maka semakin baik pula karakter anti korupsi pada diri remaja dan sebaliknya. Baik buruknya perilaku seseorang sangat ditentukan oleh pendidikan yang diperolehnya pada waktu dalam keluarganya (Salahudin dan Alkrienciehie, 2013:287). Keluarga sebagai struktur terkecil masyarakat menjadi kunci awal dalam pembentukan nilai karakter bangsa (Saleh, 2012: 10-11). Oleh karena itu Pendidikan karakter harus ada integrasi pendekatan di antara empat agen utama pendidikan, yaitu keluarga, lembaga pendidikan, masyarakat (termasuk di dalamnya institusi keagamaan), dan negara (Koesoema, 2015: 182). Di tengah kesibukannya, orang tua harus mampu menyempatkan waktunya untuk berdialog, memberi nasehat dan bercerita mengenai hal-hal positif yang mendukung karakter anti korupsi pada remaja. Orang tua juga harus peka dalam melakukan pengawasan pada segala perilaku remaja sehingga perilaku remaja dapat terkontrol. Orang tua dapat menerapkan aturan-aturan dalam keluarga yang dapat menjadi kebiasaan yang mendukung karakter anti korupsinya. Aturan-aturan itu diimbangi dengan pujian dan hukuman yang setimpal dan konsisten. Selain fokus pada masalah akademik remaja, orang tua juga harus lebih memperhatikan aspek agama pada diri remaja sebagai fondasi prinsip yang akan ia pegang hingga akhir hayatnya.

Hasil penelitian ini menggambarkan bahwa keluarga sangat berperan dalam pembentukan karakter anti korupsi dalam diri remaja. Walaupun demikian, pendidikan yang dilakukan oleh keluarga tidak selalu berhasil. Dalam kehidupan keluarga modern, situasi pendidikan anak bisa menjadi sangat problematis mengingat bahwa orang tua modern rupanya memiliki alokasi waktu yang sempit dalam menjaga dan menemani anak mereka di rumah (Koesoema, 2015: 185). Pengaruh lingkungan menjadi faktor yang juga sangat berpengaruh dalam pembentukan karakter anti korupsi remaja. Maka dari itu diperlukan pendekatan yang integral demi kesinambungan pendidikan karakter yang terjadi di dalam rumah (dalam keluarga) dan di luar rumah (di tengahtengah masyarakat) agar terbentuk generasi muda yang memiliki karakter anti korupsi.

\section{KESIMPULAN}

Berdasarkan pengolahan data penelitian dan pembahasan di Bab IV maka dapat diambil kesimpulan bahwa (1) pendidikan karakter anti korupsi dalam keluarga di SMA Negeri 53 Jakarta masuk dalam kategori sangat baik. Dimensi perumpamaan merupakan dimensi dengan skor tertinggi, diikuti oleh dimensi pembiasaan, nasehat dan menjelaskan janji dan ancaman Tuhan dengan skor yang sama dan kategori sangat baik. Dimensi dengan skor terendah yakni pengawasan yang masih masuk dalam kategori baik; (2) karakter anti korupsi pada remaja di SMA Negeri 53 Jakarta masuk dalam kategori sangat baik diimbangi oleh pendidikan karakter anti korupsi dalam keluarga responden yang juga baik. Remaja di SMA Negeri 53 Jakarta memiliki karakter adil sebagai karakter anti korupsi terbaik diikuti oleh karakter berani, mandiri dan kerja keras. Karakter jujur dan peduli merupakan karakter yang memiliki skor paling rendah; (3) pendidikan karakter anti korupsi dalam keluarga berpengaruh secara positif dan signifikan terhadap karakter anti korupsi pada remaja di SMA Negeri 53 Jakarta dengan tingkat hubungan kategori rendah. Variabel $X$ berkorelasi secara positif dengan variabel $Y$ yang menjelaskan bahwa semakin baik kualitas pendidikan karakter anti korupsi dalam keluarga akan diikuti oleh semakin baik pula kualitas karakter anti korupsi pada remaja. Hasil perhitungan uji analisis statistic menjabarkan bahwa pendidikan karakter anti korupsi dalam keluarga berpengaruh sebanyak 12,5\% terhadap karakter 
anti korupsi pada remaja, dan sisanya $87,5 \%$ dipengaruhi oleh variabel lain yang tidak masuk dalam penelitian.

\section{DAFTAR PUSTAKA}

ICW. 2010. KPK Soal Bangkrutnya Kantin Kejujuran; Pertanda Korupsi Dini. http://www.antikorupsi.org/id/ content/kpk-soal-bankrutnya- kantin-kejujuran-jadi-pertandakorupsi-dini. Diakses 19 Januari 2016.

Kementrian Pendidikan dan Kebudayaan. 2011. Pendidikan Anti Korupsi untuk Perguruan Tinggi. Kementrian Pendidikan dan Kebudayaan RI. Jakarta.

Komisi Pemberantasan Korupsi (KPK). 2014. Semua bisa ber-AKSI. KPK.Jakarta.

Koesoema, D. 2015. Pendidikan Karakter: Strategi Mendidik Anak di Zaman Global. Gramedia. Jakarta.

. (t.th). Panduan Relawan Gen Aksi: Modul Pencegahan Korupsi Berbasis Keluarga. Jakarta: KPK.

(t.th). Saya Perempuan Anti Korupsi. Jakarta: KPK.

Megawangi, R. 2009. Pendidikan Karakter : Solusi yang Tepat untuk Membangun Bangsa. Indonesia Heritage Foundation. Bogor.

Salahudin, Alkrienciehie. 2013. Pendidikan Karakter: Pendidikan Berbasis Agama dan Budaya Bangsa. Pustaka Setia. Bandung.

Saleh, M. 2012. Membangun Karakter dengan Hati Nurani:Pendidikan Karakter untuk Generasi Bangsa. Erlangga. Jakarta.

Sjarkawi. 2008. Pembentukan Kepribadian Anak. Bumi Aksara Jakarta.

Suwarsono. 2015. Resensi Buku: Captured by Evil: The Idea of Corruption in Law. Integritas: Jurnal Anti Korupsi 1(1): 160.

Transparency International. 2013. Survei Integritas Anak Muda 2013: Persepsi dan Sikap Anak Muda terhadap Integritas dan Anti Korupsi. Transparency International Indonesia. Jakarta.

Wijaya, D. 2014. Pendidikan Anti Korupsi untuk Sekolah dan Perguruan Tinggi. Indeks. Jakarta 